\title{
ANÁLISIS CRÍTICO DE LAS POTESTADES ATÍPICAS DEL JUEZ LABORAL ANTE EL PRINCIPIO DE JURIDICIDAD
}

\author{
Francisco Alberto Ruay Sáez* \\ Universidad de Chile
}

\begin{abstract}
RESUMEN: Este trabajo defiende la aplicación estricta del principio de legalidad en el proceso laboral a propósito del deber de buena fe procesal, negando que de él emanen para el juez supuestas facultades de ejecución implícitas en la ley.
\end{abstract}

Palabras clave: legalidad - buena fe - derecho del trabajo.

ABSTRACT: In this paper defends the application of the rule of law as a general principle of labor procedures and strict subordination of judges the legality.

Key words: legality - good faith - Labor Law

\section{INTRODUCCIÓN}

Nuestro legislador ha pretendido imbuir con un claro sesgo ideológico activista todas las normas procesales laborales que se consagran en el Libro V del Código del Trabajo. Así, por ejemplo, los principios formativos de impulso procesal de oficio, buena fe y celeridad, entre otros, han pretendido trasladar a la judicatura laboral elementos compensatorios propios de la naturaleza de la relación laboral misma -como podría ser la naturaleza alimentaria de los derechos en litigio-, otorgando al juez herramientas que le permitan llevar a cabo dicha tarea. En otras palabras, el Estado legislador al parecer pretende encomendar la realización de la justicia social y la redistribución de ingresos directamente al Estado Juez, para que éste, instrumentalizando el proceso como medio de realización de fines trascendentes, pueda llevar adelante la concretización dinámica de las metas políticas impuestas por el propio Estado -en este caso convendría llamarlo Gobierno-.

Expresión de la intención anteriormente descrita son las normas que pareciesen consagrar de manera atípica y abierta las potestades judiciales en sede laboral. Pero ahora, ¿es posible sostener que aquella atribución potestativa es factible en nuestro ordenamiento jurídico vigente?; ¿respeta dicha modalidad potestativa la noción misma de proceso en un Estado democrático de Derecho?; ¿cabe en el caso de los tribunales del trabajo la aplicación del principio de juridicidad?; ¿ ¿uál es el posible alcance de las normas así consagradas? Estas son algunas de las preguntas que pretendemos atender en el desarrollo del presente trabajo investigativo, intentando exponer de la manera más clara posible lo que creemos es una lectura correcta de las normas procesales pertinentes y la función jurisdiccional del Estado en sí.

\footnotetext{
Licenciado en Ciencias Jurídicas y Sociales de la Universidad de Chile. Ayudante ad honorem de la cátedra de Derecho del Trabajo y de Criminología de la misma facultad. Correo: fruay@ug.uchile.cl
} 


\section{SUJECIÓN DE LA FUNCIÓN JURISDICCIONAL DEL ESTADO AL PRINCIPIO DE JURIDICIDAD Y, EN PARTICULAR, DE LOS TRIBUNALES DEL TRABAJO}

\subsection{El Poder Judicial y la función jurisdiccional del Estado}

El poder judicial, constituido por los diversos tribunales de justicia, es la manifestación orgánica por excelencia de la faz jurisdiccional del Estado. Tal como en el caso de los demás órganos que lo componen, sostenemos que los tribunales de justicia, y en concreto, los jueces de la República empoderados para fallar en la solución de conflictos intersubjetivos, se encuentran plenamente sujetos al principio de juridicidad, tal como es comprendido por nuestra Constitución, aunque con ciertas distinciones peculiares, por la especial finalidad con la que se han otorgado las potestades a éste órgano público en concreto.

\subsubsection{El Poder Judicial y los Tribunales de Justicia como órganos del Estado}

El Estado moderno ha monopolizado el uso de la fuerza, erradicado la autotutela como forma legítima de solución de conflictos intersubjetivos, y en su lugar ha institucionalizado al proceso como medio idóneo de resolución. La labor concreta de solucionar dichos conflictos a través del proceso se encarga principalmente al Poder Judicial, y de manera más precisa, a los jueces de la República que constituyen a su vez los tribunales de justicia.

En el presente trabajo no nos referiremos de manera especial a la justicia privada o los llamados jueces arbitrales ${ }^{1}$, sino sólo a aquellos jueces que, como funcionarios públicos, son parte del Poder Judicial por disposición expresa de la ley, tanto en su faz orgánica, como en la funcional o procedimental.

El Poder Judicial ${ }^{2}$, tal como se concibe en nuestro ordenamiento jurídico, y en general en toda la tradición jurídica continental, es un órgano que forma parte del Estado. No nos enfrentamos a una organización autónoma del poder estatal surgida desde la sociedad civil para la propia resolución de sus conflictos intersubjetivos entre pares, sino que es el Estado, como persona jurídica de derecho público, quién pone a disposición de los particulares este órgano con la finalidad de que aquellos que tienen un conflicto intersubjetivo de interés encuentren la solución definitiva a su disenso, previa delegación de la resolución sustantiva del conflicto al propio Estado, representado en este caso en el Poder Judicial, y en concreto, en el juez de la causa, que para cumplir con la tarea encomendada deberá fallar conforme a Derecho, de manera imparcial, habiendo oído previamente las alegaciones de ambas partes. En este caso, al referirnos al juez, debemos comprender por tal "obviamente, al órgano del Estado que ha sido atribuido por la Constitución de la función

\footnotetext{
Árbitro es el particular -no funcionario del estado- a quien se encarga el rol de juzgador por particulares y que no tiene aptitud para ejecutar su laudo. En palabras de Alvarado Velloso "el arbitraje (o el arbitramiento) es un modo de heterocomposición de litigios que opera como resultado respecto de ellos y al cual se llega sólo si media, al menos, un principio de autocomposición de los propios interesados, por la cual aceptan plantear su litigio al árbitro (o al arbitrador) y, eventualmente, acatar su decisión”, en: Alvarado Velloso, Adolfo. Lecciones de derecho procesal civil. Botto OAkley, Hugo (Adaptador). Santiago, Chile: Punto Lex, Thomson Reuters, 2011, p. 322.

2 El Constituyente decidió utilizar la denominación clásica sólo respecto de éste órgano, no así en el caso del Legislativo y el Ejecutivo. Aquella consideración especial puede estar fundada en la especial exclusividad de la actividad judicial respecto del órgano en comento. En cambio, la función legislativa es ampliamente compartida por el Congreso y el Ejecutivo representado en la figura del Presidente de la República. En todo caso, de lo que no cabe duda es que con la nominación utilizada se vincula directamente el ejercicio de la función jurisdiccional con determinados órganos del Estado.
} 
jurisdiccional, esto es, decidir de modo independiente e imparcial contiendas entre partes, es decir, tribunales de justicia"', tal como entiende el profesor Soto Kloss.

En palabras del profesor Alvarado Velloso, "la esencia de la actividad jurisdiccional, que la tipifica de modo inconfundible por ser irrepetible en el Derecho, es la sustitución que cumple la autoridad respecto del intelecto y de la volición de los particulares en conflicto" ${ }^{4}$.

Ahora bien, tal como afirma el mismo profesor Alvarado:

"Aunque a primera vista parezca que existe una perfecta correspondencia entre cada función y cada Poder, ella no se presenta en la vida jurídica: salvo el caso del poder Ejecutivo, que no puede ni debe efectuar tarea jurisdiccional, cada una de las funciones [...] [legislativa, administrativa y jurisdiccional] es cumplida (aunque a distintos niveles) de modo concurrente por cada uno de los poderes que actúan en el Estado organizado constitucionalmente"5.

Por lo mismo, cuando hacemos referencia al Poder Judicial nos referimos preferentemente "al conjunto de jueces en su estructura orgánica, al que se encuentra confiado primeramente (aunque no en forma exclusiva) el ejercicio de la función jurisdiccional"6, considerando que hay lugar para situaciones excepcionalísimas de tribunales que no son parte del poder judicial ${ }^{7}$, y aun así se puede afirmar que por definición ejercen una función jurisdiccional; y que, además, hay casos también excepcionalísimos en que la función jurisdiccional es desarrollada por el Poder legislativo ${ }^{8}$.

Si bien es posible afirmar que no existe una relación de identidad absoluta entre cada función del Estado y los poderes tradicionales a los que suelen vincularse, en principio, para efectos de nuestro análisis, es relativamente indiferente dicha discusión teórica. Esto es así debido a que, tal como hemos concluido previamente, cualquiera de los órganos que esté ejerciendo alguna función estatal, sin importar cuál, se encuentra siempre sujeto al principio de juridicidad. Por lo tanto, además en nuestro caso, los tribunales de justicia que ejercen principalmente la función jurisdiccional del Estado, estarán sujetos al principio de juridicidad en cualquiera de las funciones que se realice en el caso concreto, debido a que el principio de juridicidad se extiende sobre todo acto realizado por cualquier órgano del Estado, sin establecer excepciones, ni en razón del órgano que actúe en nombre del Estado, ni en virtud de las características propias del acto particular que se encuentre ejecutando -resolución judicial, dictación de decreto, dictación de ley, etc.--

\footnotetext{
Soто KLoss, Eduardo. Derecho Administrativo: Bases fundamentales. Tomo II. Santiago, Chile: Editorial Jurídica de Chile, 1996 p. 39

Alvarado Velloso, Adolfo, Lecciones... (n. 1), p.126.

Alvarado Velloso, Adolfo, Lecciones... (n. 1), p. 122.

Aldunate Lizana, Eduardo. "La independencia judicial: aproximación teórica, consagración constitucional, y crítica”, en: Revista de Derecho de la Universidad Católica de Valparaíso, no XVI, Valparaíso, Chile, 1995, p. 20.

Aldunate, en un pie de página señala que "Todos los tribunales ejercen jurisdicción (esto es, la facultad de desarrollar y satisfacer la función jurisdiccional) art. 73 i. I [actualmente art. 76 i. I]. Y en principio, sólo ellos [...] Pero hay tribunales que no forman parte del Poder Judicial: art. 73. [actualmente art. 76]. La misma Constitución menciona al menos tres: TC, TCE Y tribunales electorales regionales". Ibid., p. 20.

Art. $52 \mathrm{n}^{\circ} 2$ y $53 \mathrm{n}^{\circ} 1$ de la Constitución de la República, sobre el conocimiento de las acusaciones a las que allí se hace referencia; y art. $53 \mathrm{n}^{\circ} 3$ de la Constitución, sobre contiendas de competencia. En: Ibíd. p.19. En opinión de Alvarado Velloso procedería sólo en el caso del juicio político Alvarado Velloso, Adolfo, Lecciones... (n. 1), p. 122.
} 
En consecuencia, y de manera evidente, no sólo el ejercicio de la función administrativa desarrollada por parte del Poder Judicial ${ }^{9}$ queda cubierta por el principio de juridicidad, como podría llegar a pensarse si se relaciona este principio netamente con la función ejecutiva del Estado, sino que lógicamente este órgano también se encuentra sujeto al principio de juridicidad en el ejercicio de la función jurisdiccional.

La función jurisdiccional del Estado, a su vez, se satisface y materializa en la heterocomposición pacífica de los conflictos intersubjetivos de intereses por parte de un juez o tribunal imparcial $^{10}$, a través de un proceso judicial, lo que nos permite concluir que concretamente el juez, en el desenvolvimiento dialéctico del proceso, deberá sujetar su actuación al principio de juridicidad, en tanto órgano del Estado.

Es posible deducir de manera lógica la sujeción de los tribunales de justicia establecidos en la ley, al principio de juridicidad consagrado en los artículos $6^{\circ}$ y $7^{\circ}$ de la Constitución, desde la verificación conceptual de que estos en tanto constituyen el Poder Judicial son órganos del Estado $^{11}$. Luego, al analizar la descripción clásica del principio ${ }^{12}$, no queda lugar a duda, y la aplicación del silogismo es evidente. A pesar de aquello, diversos autores no han dudado en referirse de manera explícita al Poder Judicial y los tribunales de justicia a propósito de la descripción de su configuración y posición orgánica. Así, por ejemplo Jorge Reyes al referirse a los órganos estatales sometidos al principio de juridicidad señala que "si es el Estado quien se encuentra obligado por este principio, quiere decir que todos sus órganos, sin excepción alguna, también lo están. Es decir, si el Gobierno se halla en este deber, también lo está [...] el Poder Judicial [...]"13. En el mismo sentido el profesor Hugo Caldera señala que "Sería un grave error circunscribir los efectos de la juridicidad al ámbito de la administración del Estado, en atención a que dicho principio también obliga a los tribunales de justicia. A título de ejemplo indicamos que el ejercicio de la función jurisdiccional también está sujeto al citado principio [...]"14, y el profesor Soto Kloss por su parte afirma que "el juez [...] también debe someter su acción a la Constitución, y a las normas dictadas conforme a ella y, por lo tanto rige a su respecto igualmente en plenitud e integralidad el princi-

Por ejemplo, en la designación del personal del propio tribunal, o en el desenvolvimiento de la superintendencia económica de la Corte Suprema, como manifestaciones de algún grado de autonomía o independencia del Poder Judicial. Sin embargo, tal como señala Aldunate: "la idea de esta autonomía es crear un espacio de regulación y gestión excluido de los demás poderes, para permitir a la propia estructura judicial configurar sus "aspectos domésticos". No existe, sin embargo, una reserva frente al legislador: la ley siempre podrá entrar a regular estos aspectos” Aldunate Lizana, Eduardo, op. cit. (n. 6), p. 21.

10 Por disposición expresa de la Constitución en su artículo 76 se señala que: "[l]a facultad de conocer de las causas civiles y criminales, de resolverlas y de hacer ejecutar lo juzgado, pertenece exclusivamente a los tribunales establecidos por la ley".

11 "No cabe duda alguna que la función jurisdiccional, concretada orgánicamente en los tribunales de justicia, está comprendida dentro de la actividad que desarrollan los órganos del Estado, puesto que la disposición indicada [art. $6^{\circ}$ Constitución] se refiere genérica y globalmente a todos los órganos públicos". Caldera Delgado, Hugo. Sistema de la responsabilidad extracontractual del estado en la constitución política de 1980. Santiago, Chile: Editorial Jurídica de Chile, 1982, p. 30.

12 "La sujeción integral a Derecho de los órganos del Estado tanto en su ser como en su obrar" Soto Kloss, Eduardo. Derecho... (n. 3), p.24.

13 Reyes Riveros, Jorge. "Los principios aplicables respecto del papel instrumental del Estado frente a los derechos y deberes de las personas”, en:_Revista de Derecho Público, Vol. 62, Santiago, Chile, 2000, p. 149. En otro lugar señala categóricamente que el artículo 6 de la Constitución "hace aplicable el principio a las funciones y acciones. Ni la ley, ni la sentencia ni el decreto ni el acto de la toma de razón o de representación ni cualquier otro acto del Estado quedan al margen del principio”, en: ReYEs Riveros, Jorge. "El principio de juridicidad y la modernidad", en: Revista chilena de derecho, Vol. 25, no 1, Santiago, Chile, 1998, p. 87

14 Caldera Delgado, Hugo. Tratado de Derecho Administrativo. Tomo I. Santiago, Chile: Ediciones Parlamento, 2001 , p. 87. 
pio de juridicidad"15. Por su parte, los profesores Jorge Bermúdez ${ }^{16}$ y Gustavo Fiamma ${ }^{17}$ también reconocen explícitamente la aplicación del principio de juridicidad respecto de los tribunales de justicia.

Recurriendo a la historia fidedigna de la de la Constitución, encontramos opiniones en esta misma dirección:

"El señor Evans estima que no se debe circunscribir la posibilidad de desviación de poder, en lo abusivo o ilegítimo de una facultad, exclusivamente al Poder Ejecutivo, ya que el Congreso Nacional -como se ha dado en Chile- o el Poder Judicial pueden caer en infracciones derivadas de un ejercicio abusivo de sus funciones [...] El señor Guzmán, fundamentando su posición, expresa que el concepto de desviación de poder, en lo sustantivo, es aplicable a cualquier órgano del Estado" 18 .

Desde otro enfoque es posible llegar a la misma conclusión si se comprende la función judicial como una manifestación del ejercicio soberano del poder. El juez, al ejercer la función jurisdiccional del Estado, no está sino actuando en nombre de la soberanía estatal, y en realidad, ejerciendo la soberanía que recae sobre la nación. En ese sentido, tal como señala Bordalí, "que el judicial sea un poder soberano indica fundamentalmente que se trata de un poder jurídico, de un poder del Estado. Dicho de otro modo, hay que concordar en que los jueces ejercen una de las funciones estatales" 19 .

Un último argumento que refuerza nuestra posición se encuentra en la responsabilidad del Estado surgida del error judicial. La doctrina que se ha hecho cargo de ésta particular responsabilidad, si bien ha discutido sobre los presupuestos de la acción indemnizatoria, no han puesto en discusión que es el Estado quién se posiciona como legitimado pasivo. Para ser más preciso, se habla del Estado-Juez, para referirse particularmente a este tipo de situaciones. "La indemnización por error judicial se enmarca dentro del género de la responsabilidad del Estado. La responsabilidad del Estado es el género, y la responsabilidad por error judicial es la especie"20, afirma el profesor Carmona. Soto Kloss, por su parte, cree que la responsabilidad que surge para el Estado a propósito del ejercicio de la actividad jurisdiccional no debe limitarse sólo a los casos de error judicial, propios del área penal, sino que abarca todas las posibilidades de actuación del Estado-Juez ${ }^{21}$, lo que permitiría alcanzar una comprensión unitaria de la responsabilidad del Estado. En un sentido similar opina el profesor Caldera cuando señala que "los requisitos para la

\footnotetext{
15 Soto Kloss, Eduardo. Derecho Administrativo... (n. 1), p. 39 y también Soto KLoss, Eduardo. "La nulidad de derecho público: su actualidad”, en: Revista de Derecho de la Pontificia Universidad Católica de Valparaíso, n 18, Valparaíso, Chile, 1997, p. 348.

16 Bermúdez Soto, Jorge. "El principio de legalidad y la nulidad de Derecho Público en la Constitución Política. Fundamentos para la aplicación de una solución de Derecho Común”, en: Revista de Derecho Público, Vol. 70, Santiago, Chile, 2008 p. 273.

17 Fiamma Olivares, Gustavo. "Acción constitucional de nulidad y legitimación activa objetiva”, en: Revista de Derecho Público, $\mathrm{n}^{\circ}$ 49, Santiago, Chile, 1991, p.92.

18 Actas oficiales, Sesión 50, celebrada el 2 de Julio de 1974, p. 17 citada en: Cea Egaña, José Luis. Derecho Constitucional Chileno. $-2^{\circ}$ edición-. Santiago, Chile: Ediciones Universidad Católica de Chile, Santiago, 2008, p. 249.

19 Bordalí Salamanca, Andrés. "La doctrina de la separación de poderes y el poder judicial chileno", en: Revista de Derecho de la Pontificia Universidad Católica de Valparaíso, n 30, Valparaíso, Chile, 2008, [En línea]. [Consultado 20 de Marzo de 2012] < http:// www.scielo.cl/pdf/rdpucv/n30/art04.pdf> p. 193.

20 Carmona Santander, Carlos. "La Responsabilidad del Estado-Juez. Revisión y Proyecciones", en: Revista de Derecho Público, $n^{\circ}$ 66, Santiago, Chile, 2004, p. 309

${ }^{21}$ Sото KLoss, Eduardo. "Responsabilidad del Estado por la actividad jurisdiccional (notas para un enfoque unitario de la responsabilidad extracontractual del Estado)", en: Revista chilena de derecho, Vol. 10, no 1, Santiago, Chile, 1983, pp. $45-58$.
} 
puesta en juego de la responsabilidad extracontractual por el acto jurisdiccional, los estimamos excesivamente restrictivos, al punto de llegar parecer mezquino el estado juez comparándolo con el Estado administrador"22. En todos estos casos, es evidente que si es el Estado quién debe responder patrimonialmente por las actuaciones indebidas del poder judicial, es simplemente porque éste actúa a nombre del primero, es una manifestación particular del poder concentrado en el Estado; se trata del Estado-Juez. Aquello va aparejado de la idea de que el poder estatal es único e indisoluble, y por lo mismo, el sujeto que se encuentra tras sus diversas actuaciones es siempre la unidad del Estado.

\subsection{LA FUNCIÓN JURISDICCIONAL DEL ESTADO COMO UNA ACTIVIDAD REGLADA Y VINCULADA DESDE EL PRINCIPIO DE JURIDICIDAD}

Previamente hemos expuesto las razones que nos permiten afirmar que la función jurisdiccional desarrollada por el Estado, en tanto se desenvuelve por sus propios órganos, se encuentra plenamente sujeta al principio de juridicidad. En las siguientes líneas nos limitaremos a enunciar aquellos aspectos del principio en cuestión que son especialmente relevantes tratándose del ejercicio de la función jurisdiccional por parte del Poder Judicial y en la resolución del Proceso.

A continuación analizaremos cuál es el alcance del principio de juridicidad respecto de los tribunales de justicia que ejercen la función jurisdiccional del Estado.

\subsubsection{Principio de juridicidad y Garantismo procesal; la Constitución sobre el ejercicio de la función jurisdiccional}

La función jurisdiccional desarrollada por el Estado consiste fundamentalmente en la resolución de conflictos intersubjetivos, previo desarrollo de un proceso. Por lo tanto, las potestades otorgadas al tribunal respectivo, en la dimensión relevante para nuestro análisis ${ }^{23}$ tienen como finalidad que dicho órgano guíe el desarrollo dialéctico del proceso. En otras palabras, es posible afirmar que el proceso es el medio por el cual los órganos del Estado llevan a cabo la función jurisdiccional, y por tanto, es en el desarrollo del proceso mismo que el órgano en cuestión se encuentra sometido al principio de juridicidad.

La dimensión normativa relevante en nuestro análisis se encuentra en la ley procesal. Será ésta la encargada de definir las atribuciones del tribunal para el desarrollo correcto del proceso. Esto considera las normas procedimentales, y también las orgánicas, vinculando al órgano tanto en su finalidad, como en su constitución y organización. Esto implica, indirectamente, que el tribunal correspondiente, en la resolución final del caso también se encuentra sujeto al principio de juridicidad. En el ejercicio hermenéutico que lo llevará acoger o rechazar la pretensión alegada en juicio, mediante una argumentación jurídica racional contenida en la sentencia, está desarrollando su labor, y ejerciendo facultades, en un momento del desarrollo dinámico y continuo de la función jurisdiccional. Ahora, la particularidad en este caso, es que un aspecto esencial de la función jurisdiccional es que ésta se encuentra orientada a la mantención del orden social, sin que se pierda un grado razonable de previsibilidad de las actuaciones del Estado, con la finalidad de incrementar y hacer posible, en último término, el ejercicio de la libertad individual. La cosa

\footnotetext{
22 Caldera Delgado, Hugo, Sistema... (n.11), p. 36.

23 Un análisis de otro tipo podría realizarse a propósito de las facultades económicas, disciplinarias, y en general, de administración interna, con la que cuentan algunos tribunales de justicia.
} 
juzgada, el principio de legalidad, y la reserva legal procesal ${ }^{24}$, en concreto, se encargan de otorgar la estabilidad y certeza jurídica requeridas; con la resolución que constituye sentencia de término del respectivo juicio, se da fin al conflicto intersubjetivo que dio origen al proceso, y mediante este acto estatal de clausura se extingue también el ejercicio de esta función ${ }^{25}$.

Si la función jurisdiccional del Estado desarrollada por el juez se sujeta al principio de juridicidad, aquello implica que los diversos procedimientos en que se concretiza la atribución de potestades a los jueces, han de concebirse, precisamente, desde dicho principio. Pero además, y tal como expusimos en la primera parte de la investigación, comprendemos los fines del proceso desde la doctrina del garantismo procesal. Desde esa posición es posible sostener que la ley otorga potestades finalizadas en un cierto sentido; no queda al arbitrio de cada uno de quienes ejerzan la jurisdicción decidir cuál es la finalidad de las potestades que le han sido atribuidas, por ejemplo, obviando disposiciones legales para alcanzar la captura mística de la polémica "verdad material".

La sujeción de la función jurisdiccional al principio de juridicidad es plenamente coherente con la concepción garantista del proceso. En razón de aquello, sostenemos que es posible un acercamiento a dicho fenómeno desde ambos fundamentos teóricos, de manera simultánea y comprehensiva. La consagración del principio de juridicidad en nuestra Constitución de contenido eminentemente liberal, permite fundar una comprensión del proceso coherente con el garantismo procesal, a la vez que esta última noción otorga herramientas para la correcta comprensión de las potestades atribuidas en particular al órgano que ejerce la función jurisdiccional.

La primacía de la persona humana, consagrada en nuestra Constitución, se encuentra como idea fundamental tanto en la doctrina del garantismo procesal, como en el principio de juridicidad. El respectivo resguardo del individuo ante el poder que ejerce el Estado que ha monopolizado el uso de la fuerza, permite también modelar conceptualmente la comprensión del ejercicio de la función jurisdiccional, y el carácter y alcance que ha de tener la configuración de potestades del juez en el desarrollo del proceso.

\subsubsection{Habilitación legal previa, y vinculación positiva de la función jurisdiccional}

Ahora bien, desde el principio de juridicidad particularmente consagrado en nuestra Constitución, es posible desprender determinadas consecuencias para todos los órganos que pretendan actuar válidamente. Dichos elementos tendrán un significado especial tratándose del órgano que ejerce la jurisdicción.

Recordemos brevemente que tal como se han interpretado los textos normativos del artículo $6^{\circ}$ y $7^{\circ}$ de la Constitución, para que pueda considerarse válida la actuación de cualquier órgano del Estado es necesaria siempre la habilitación legal previa y expresa. Por tanto, queda de entrada absolutamente descartada la posibilidad de que el órgano respectivo, en nuestro caso el judicial, pueda auto atribuirse potestades ${ }^{26}$, y también se excluye manifiestamente la posibilidad de interpretar la norma procesal potestativa en un sentido tal que diese cabida a la teoría de las potestades

\footnotetext{
24 “Toda sentencia de un órgano que ejerza jurisdicción debe fundarse en un proceso previo legalmente tramitado. Corresponderá al legislador establecer siempre las garantías de un procedimiento y una investigación racionales y justos” Art. 19 n 3 inc. 5 de la Constitución.

25 Cabe señalar que también está facultado, en el ejercicio de la jurisdicción, para hacer ejecutar lo resuelto coactivamente. Este elemento diferencia el ejercicio público de la función jurisdiccional con el árbitro como juzgador privado, y es manifestación de la sustitución por parte de la autoridad, tanto de la violencia institucionalizada, como del elemento volitivo de los particulares que se encuentran en litigio.

26 Aunque en realidad parece una paradoja: si se permite un ejercicio arbitrario del poder ya no estamos en presencia de su ejercicio legítimo, y por tanto no hay potestad, sino un mero acto de violencia ilegítima.
} 
implícitas, ya que la Constitución señala de manera literal que la atribución correspondiente ha de realizarse siempre de manera explícita.

En nuestro sistema jurídico, tal como señalamos previamente, el principio de juridicidad es comprendido en la generalidad de los casos desde el criterio de vinculación positiva. En virtud de aquello, la potestad conferida en la ley respectiva -ley procesal- define la validez de la actuación realizada por el órgano judicial, toda vez que se limita a realizarlo que previa y expresamente le esté permitido. En ese sentido, siempre el juez respectivo que pretenda guiar el proceso en una determinada dirección, o decretar cualquier actuación en él, necesita fundar la misma, para que sea válida, en alguna norma jurídica potestativa, y jamás podrá aprovechar la ausencia de regulación para encontrar un espacio legítimo de actuación estatal. Esto significa que no le corresponde en ningún caso la creación de norma procesal $a d h o c^{27}$, pues no se le reconoce un ámbito de libertad o autodeterminación normativa, y en tanto órgano del Estado, sólo puede actuar allí donde la ley o la Constitución se lo ordene, siempre de la forma en que dichos textos normativos prescriban. La vinculación positiva además excluye las posibilidades de que el juez pudiese interpretar analógicamente la ley procesal, en razón de los argumentos ya señalados.

Cabe recordar, sobre el mismo punto, que en nuestro sistema jurídico, conforme al principio de juridicidad y de separación de poderes ${ }^{28}$, la función jurisdiccional realizada por los jueces, se encuentra necesariamente diferenciada de la función nomogenética. Garantizamos de esta manera el contenido democrático con que ha de estar impregnada la función legislativa, a la vez que situamos un necesario presupuesto de la posición imparcial que ha de tener el juez a quien se encomienda la resolución de algún conflicto de relevancia jurídica. Aparece como razonable, y lógico, que en nuestro sistema jurídico de tradición legalista, no coincida en la misma persona la generación del Derecho y la aplicación concreta del mismo.

En este sentido se puede afirmar que es en virtud del propio principio de juridicidad que le está vedada la posibilidad de crear norma jurídica procesal ad hoc al juez, con la finalidad de resolver el caso concreto. Eso sí, habría que distinguir la situación propuesta de aquellos casos en que en virtud de la dictación de un auto acordado pretende el Poder Judicial regular de manera general y abstracta alguna situación interna, eminentemente de carácter administrativa. En otras palabras, lo que sostenemos es que la coincidencia simultánea de la función jurisdiccional con la función nomogenética -especialmente de carácter procesal- es vulneratoria del principio de juridicidad, pero una discusión diversa se genera si al separar dichas funciones intentamos analizar la viabilidad de reconocer alguna función legislativa en el Poder Judicial -ahora como agente estático, no en el ejercicio de la función jurisdiccional-; discusión que no es pertinente de tratar en la presente investigación.

\subsubsection{El desarrollo del proceso como realización finalizada de la función jurisdiccional del Estado: exclusión de potestades implícitas y atípicas}

En el caso de la función jurisdiccional sucede algo particular que permite distinguirla de las otras dos funciones estatales -legislativa y ejecutiva-. En este caso prácticamente coincide el re-

\footnotetext{
Un problema diferente se presenta al adentrarse en el análisis de la potestad que ejerce la autoridad respectiva al dictar un auto acordado.

28 "Su rol de control en el estado de Derecho es de carácter jurídico [...] para cumplir el rol de control jurídico bajo el principio de separación de poderes, la función jurisdiccional deb[e] encontrarse disociada tanto material como orgánicamente de las demás funciones y órganos a controlar: de la función de gobierno y administración y de la función nomogenética". Aldunate Lizana, Eduardo, "La independencia... (n. 6), p.17.
} 
quisito de validez de la actuación estatal con la función estatal misma -su finalidad-. El desarrolle del proceso, y el procedimiento en que se concretiza, se encuentran previamente establecidos en la ley, y el agente estatal en este caso cumple su función guiando la discusión bilateral conforme al principio de igualdad, precisamente actuando sólo de la manera que esté previsto en dicho texto normativo. O sea, el procedimiento -forma- establecido para la validez de la actuación del órgano estatal $^{29}$, coincide con la realización final de la función misma.

El procedimiento, a la vez que otorga facultades, al constituirse como proceso, representa la realización misma de la función que se le ha encargado al órgano. En el devenir del proceso contradictorio el órgano respectivo realiza la finalidad para la que le fue atribuida una determina potestad y autoridad. No existe un bien trascendente a la solución del conflicto que permita argumentar la posibilidad de que la función jurisdiccional del Estado no ha sido satisfecha, y por tanto, en virtud de aquella -como podría ser la verdad, la aplicación de políticas públicas, o inclusive su generación normativa- se pudiese argumentar, por ejemplo, que el juez posee potestades implícitas o atípicas. El rol del juez no se extiende más allá de la resolución del conflicto en el caso concreto, y esto significa en su reverso la mantención del orden y la paz social, en tanto logra esa composición, por lo mismo, con mayor razón es posible descartar de plano la inclusión de la doctrina de las potestades implícitas en este ámbito.

Podría justificarse que la solución definitiva al conflicto intersubjetivo de relevancia jurídica, en tanto constituye la finalidad de la potestad atribuida al juez, permitiría por sí sola la generación de potestades implícitas. Sin embargo, si la finalidad de la función jurisdiccional no tiene otro contenido más que aquél, dicha atribución abierta acarrearía más problemas que soluciones. De hecho, se abren espacios mucho más amplios a la arbitrariedad judicial, y al poder Estatal por sobre la libertad, y los intereses individuales que son puestos en juego en el proceso. Cada juez, caso a caso, podría sorprender con medidas que a su particular intelecto aparezcan idóneas para lograr la finalidad última de la función que se le ha encargado: la solución definitiva y pacífica de un conflicto intersubjetivo de relevancia jurídica, pero sin embargo, el fundamento mismo de esa potestad carecería de una sustantividad tal que oriente el contenido de la resolución en un determinado sentido, por lo que cabría concluir que caso a caso sólo estaría realizando su propia voluntad subjetiva, revestida del poder Estatal, quién sabe con qué fines.

Además, por razones de constitucionalidad esta doctrina no tendría cabida en nuestro sistema jurídico. Aceptar la posibilidad de que existan potestades atípicas o implícitas atribuidas al juez supondría que, a diferencia de quienes ejercen las otras funciones estatales, o los otros poderes del Estado, el juez ejercería un poder no vinculado y de dificultoso control -externo o interno-. Se abre la posibilidad de que el juez actúe arbitrariamente contrariando las respectivas garantías procesales establecidas a favor de las partes, y no tan sólo eso, sino que al dejar de ser un poder vinculado se desnaturaliza absolutamente la función jurisdiccional y la posición del juez como tercero imparcial. Si por definición el Estado sólo puede extender su poder allí donde le es explícitamente permitido, dar cabida a atribuciones implícitas de los jueces atenta de manera desmedida contra la certeza jurídica y el principio de igualdad.

\footnotetext{
29 En el caso del Derecho Administrativo pareciese que la finalidad del acto siempre es exterior al procedimiento que ha de darle origen, y que se materializa en el expediente administrativo. Hay un objetivo perseguido por la administración que trasciende la realización del mero procedimiento unilateral que valida su actuación. En este caso, estamos ante un procedimiento legitimante de la actuación del Estado, pero no frente a un Proceso. En el caso de la función jurisdiccional la realización del Proceso basta para su satisfacción, pues no hay una finalidad política de contenido trascendente que se pretenda alcanzar con el resultado final del proceso.
} 
Definitivamente con el solo hecho de instalar la doctrina de las potestades jurídicas implícitas se está restringiendo de manera considerable el ejercicio de la libertad individual. La imposibilidad de prever cuáles serán las formas que establecerá el Estado actuando desde el estrado para la defensa de los propios intereses vulnera innecesariamente y de manera ilegítima las posibilidades de autodeterminación de los particulares, no sólo frente a sus pares, sino que aún más grave; frente al poder del Estado, y le otorga a éste último un ámbito de actuación en donde pareciera no requerir habilitación legal previa para la validez de la misma; esto es, una apertura a la arbitrariedad del poder.

Si no fuese necesaria la habilitación legal previa, y no primara la vinculación positiva respecto de las potestades conferidas a los órganos del Estado, estaríamos aceptando la posibilidad de que éste tenga intereses propios, y por lo mismo, que pudiese auto determinarse y fijar sus metas y fines desde sí y para sí. En el caso de los jueces, en particular, el reconocimiento de potestades implícitas supone la desnaturalización del proceso, en donde el juez, que representa al Estado en el juicio, debiese ser un tercero imparcial desinteresado. Hay que recordar que especialmente en el caso de la función jurisdiccional, las normas procedimentales consisten en sí mismas en garantías que permitirán el desarrollo del contradictorio, dialéctico y bilateral, en un pie de igualdad ante un tercero imparcial, y de esta manera, se resguarda que el juez ejerza en el proceso sólo la función jurisdiccional del Estado, pero en ningún caso la legislativa o ejecutiva. Esa separación de funciones es garantía de la libertad.

Sujetar al juez al principio de juridicidad no implica limitar externamente sus posibilidades de actuación, pues la realidad es que no tiene más que aquellas que se encuentran previamente definidas en la ley. Aunque no se quiera comprender así, al juez, en tanto también es Estado, no puede reconocérsele un ámbito de libertad que no le es propio. El juez no tiene facultades de ningún tipo previo a que la propia ley y la Constitución así lo dispongan, sostener lo contrario implica desatender el diseño institucional orgánico que nuestra propia Constitución define.

En una correcta interpretación de nuestro texto Constitucional las potestades atribuidas al juez no tienen como finalidad que éste concretice algún interés estatal autónomo, que se extienda más allá de la mantención del orden social. En consecuencia, no correspondería a una figura de Estado activista, sino más bien reactivo, en la terminología de Damaska. Cada una de las actuaciones procesales que realiza el juez en el desarrollo del proceso, incluyendo la sentencia que dicta para poner término al mismo, debe ser coherente con la comprensión del Estado que sostiene nuestra Constitución. Así, no se busca en cada acto la intervención activa del Estado, sino más bien, y en concordancia con el garantismo procesal, el juez en tanto representante del Estado debe intervenir lo menos posible en el desarrollo dialéctico del debate entre las partes, con la finalidad de que su posición de tercero imparcial no se vea perturbada, afectando así las garantías procesales de las partes.

En conclusión, hasta este punto hemos señalado que la actuación válida del órgano que ejerce la jurisdicción requiere habilitación legal previa -ley procesal-; que además esa previa habilitación está determinada como vinculación positiva, y por tanto el juez puede actuar sólo conforme lo señala la ley; esto significa a su vez que no cabe la interpretación analógica de la ley procesal, y que tampoco puede el juez actuar en nombre de una determinada finalidad deduciendo supuestas potestades implícitas, en caso de que considere que se encuentra ante situaciones no regladas de manera previa y expresa, señalando que los únicos límites a su actuación son las garantías individuales o cualquier otra restricción contenida en la ley. Lo anterior implica que la atribución de potestades no se realiza de manera abierta, sino acabada, pues no se reconoce que el Estado pueda actuar, en cualquiera de sus dimensiones, ejerciendo algún ápice de libertad, ya 
que esta última sólo es constitutiva de la persona humana, más no de la ficción instrumental que representa el Estado.

\subsubsection{Potestades judiciales regladas y discrecionales}

En relación con la forma en que pueden ser atribuidas las potestades jurisdiccionales, es posible distinguir entre potestades regladas y discrecionales. Sintéticamente se puede señalar que; en el caso de la primera, todos los elementos que constituyen la potestad se encuentran definidos de manera acabada y completa ${ }^{30}$; mientras que en la potestad discrecional se ha otorgado un margen de elección al empoderado, en este caso el juez, para que escoja entre medidas igualmente justas que han sido definidas previamente la ley.

Pero discrecionalidad no es lo mismo que arbitrariedad. Un acto arbitrario supone un ámbito de libertad absoluta, en cambio en el caso de un acto discrecional se encuentran previamente definidas las vías alternativas que son consideradas igualmente válidas. Por lo mismo, no hay lugar a la atribución de potestades judiciales abiertas o en blanco, pues aquello implicaría decididamente abrir espacio a la arbitrariedad, y reconocer que el Estado es titular de algún tipo de libertad que constitutivamente no le es propia. En ese sentido, lo que sí podría eventualmente ocurrir es que una potestad cualquiera conferida al juez puede facultarlo a que éste escoja en determinados casos entre alternativas igualmente válidas, pero para que aquello sea posible hay ciertos elementos de la potestad que no puede dejar de estar presentes ${ }^{31}$, incluyendo obviamente la descripción acabada de las vías alternativas.

En el caso del juez resulta particularmente compleja la atribución de potestades discrecionales, pues implica reconocerle al menos un ámbito de participación activa en el desarrollo del debate dialéctico llevado a cabo por las partes, arriesgando con ello su imparcialidad, y abriendo paso a la eventual vulneración de garantías procesales de rango constitucional. Por lo mismo, ha de interpretarse restrictivamente aquel empoderamiento de los jueces, y desde el garantismo procesal, se debe prevenir que el proceso no deje de ser tal, con la finalidad de que las partes involucradas no vean vulneradas sus garantías fundamentales, y menos que el Estado logre legitimar un espacio de arbitrariedad e intervención, tras la retórica del ejercicio de una potestad discrecional que no es tal.

\subsubsection{La utilización de conceptos juridicos indeterminados en la atribución potestativa judicial}

La utilización de conceptos jurídicos indeterminados en la configuración potestativa de los jueces asienta una grieta insoslayable en la certeza jurídica. Si bien su inclusión se justificaría por su carácter laxo, y porque a través de estos conceptos el Derecho positivo podría hacerse cargo del dinamismo social y cultural, es precisamente éste su mayor defecto. Es obvio que el Estado debe hacerse cargo de los cambios de concepciones jurídicas a raíz de las modificaciones y avances en la comprensión del mundo, sin embargo en la realización de dicha labor no se puede obviar la primacía de la persona humana, y las posibilidades de autodeterminación con que cuentan los particulares. Precisamente, al incluir conceptos jurídicos indeterminados al final del día, el costo de hacernos cargo de la dinámica del mundo práctico, es generar inseguridad jurídica en los

\footnotetext{
30 Soto Kloss, Eduardo. Prólogo, en: Alarcón Jaña, Pablo Andrés. Discrecionalidad administrativa. Un estudio de la jurisprudencia chilena. Santiago, Chile: Editorial Jurídica ConoSur Ltda., 2000.

$31 \quad$ Ibid.
} 
operadores del sistema, y la sociedad civil en general, que queda entregada al ejercicio del poder estatal en un caso concreto.

Hay quienes razonablemente intentan fundar la aceptación de los conceptos jurídicos indeterminados en la descripción típica de las potestades conferidas a los órganos del Estado, afirmando que en su realización concreta sería posible dilucidar una sola respuesta correcta. Esto es, el contenido mismo del concepto se determinaría en último término por las circunstancias contingentes del caso particular, de los que debe hacerse cargo el operador jurídico que esté facultado para actuar; en este caso, el agente estatal respectivo.

En el caso de la función jurisdiccional nos encontramos con un problema gravísimo. Se espera que en virtud de la seguridad jurídica, y de las garantías procesales mínimas, las partes de un juicio conozcan previamente, al menos, las normas del procedimiento a través del cual se guiará la discusión. Debe conocer de manera previa las actuaciones procesales que le es necesario realizar para lograr convencer al juez de que su posición argumentativa es la correcta; de lo contrario, la intervención judicial ad hoc no respetaría las normas del debido proceso, afectando especialmente su posición imparcial. La certeza jurídica posibilita el ejercicio de la libertad individual, y ésta debe resguardarse, en primer lugar, en el desarrollo mismo del proceso llevado ante un juez.

Obviamente la decisión de fondo del caso implica también el ejercicio de una potestad jurisdiccional, y por lo mismo, ha de esperarse de ella la misma previsibilidad, aunque en este caso, el derecho sustantivo pudiese dar lugar a mayores vías argumentativas posibles y coherentes, que finalmente podrán legitimar la dictación de la sentencia en uno u otro sentido.

Lo anterior nos guía a sostener que conforme al principio de juridicidad, y desde de una perspectiva garantista, cada vez que se utilice un concepto jurídico indeterminado, para no vulnerar las garantías procesales de las partes, el debido proceso, y hasta la propia norma constitucional sobre juridicidad, ha de realizarse una interpretación restrictiva, limitando en lo posible la concreción del concepto jurídico utilizado, a los casos completamente tipificados en la ley, que sean manifestación o expresión de su sentido o espíritu último. De lo contrario, nos encontraríamos en una situación abierta a la inseguridad jurídica e imprevisibilidad de las actuaciones del Estado, en donde caso a caso el particular que lleve su conflicto a juicio no tendrá que atenerse al Derecho democráticamente promulgado, y a las formas procesales que han sido legalmente establecidas de manera previa, sino que a la personalidad del juez de la causa, la visión que éste tenga sobre el rol del Estado y el alcance de las libertades individuales, reduciendo además considerablemente las posibilidades de control racional de sus resoluciones.

Si hay algún órgano que se encuentra legitimado para convertir en Derecho vinculante la dinámica social contingente, éste coincide con aquel legitimado para ejercer la función legislativa ${ }^{32}$. El ejercicio de la función jurisdiccional, tal como señalamos previamente, se encuentra constitutivamente diferenciado de la función nomogenética del Estado. No puede por tanto el juez crear ningún texto normativo vinculante, ni norma procesal ad hoc, ya que el diseño institucional orgánico de nuestro Estado permite afirmar que dichas funciones han de ser ejercidas por agentes

\footnotetext{
32 Compartida mayoritariamente, y conforme al principio de reserva legal, entre el Ejecutivo, representado en su grado jerárquico más elevado, por el Presidente de la República; y el Congreso, sobre las materias de ley a las que se refiere la propia Constitución. Puede argumentarse que la generación normativa también se encuentra excepcionalmente radicada en la Corte Suprema y la Corte de Apelaciones, a propósito de su facultad para dictar autos acordados en virtud del art. $82 \mathrm{n}^{\circ} 1$ de la Constitución. Sin embargo, dicha afirmación es sumamente aventurada, pues aún no se encuentra clarificada plenamente la naturaleza jurídica de dichos textos normativos, y a lo sumo se ha señalado que no son ni leyes, ni decretos, ni resoluciones jurisdiccionales, por lo que serían una fuente de Derecho heterodoxa.
} 
diversos. En último término, esta separación actúa siempre como garantía para particulares frente al poder del Estado.

En conclusión, al igual que en el caso de los demás órganos del Estado, no es posible aceptar la existencia de potestades atípicas del juez en nuestro ordenamiento jurídico, pues conforme al principio de juridicidad las potestades otorgadas al Estado Juez se encuentran siempre tipificadas en todos sus elementos, o al menos aquellos esenciales que excluyen la arbitrariedad del órgano respectivo, y vinculan positivamente a quién ejerce la función jurisdiccional del Estado, orientada fundamentalmente a la resolución pacífica de un conflicto intersubjetivo de intereses de relevancia jurídica. Además, sostenemos que el correcto ejercicio de las potestades conferidas al juez se realiza en la medida que se entienden los fines del proceso y la función jurisdiccional desde el garantismo procesal.

\subsubsection{Los juzgados de letras del trabajo sujetos al principio de juridicidad}

Hasta aquí hemos hablado de quienes ejercen la función jurisdiccional del Estado en general, sin embargo todo lo que hemos señalado es plenamente aplicable respecto de cualquier órgano particular que ejerza dicha función; en nuestro caso lo relevante es que es plenamente aplicable a los juzgados de letras del trabajo.

Desde un punto de vista orgánico, los juzgados de letras del trabajo, son parte del Poder Judicial, y constituyen un tribunal de carácter especial. Así lo señala el artículo 5 del Código Orgánico de Tribunales ${ }^{33}$ y el artículo 417 del Código del Trabajo ${ }^{34}$. Éste último consagra en su artículo 415 la dimensión organizacional de los juzgados, la competencia territorial de estos tribunales y los jueces que integran cada uno de aquellos.

Podría pensarse que en virtud de la supuesta autonomía del derecho procesal laboral, lo que hemos señalado previamente no es aplicable en el caso de que quién ejerce la función jurisdiccional sea un juez laboral. Sin embargo, esa supuesta autonomía, no extiende su alcance al punto de generar paralelamente una nueva noción de proceso que la haga posible. Sin duda el procedimiento que deberá aplicar el juez laboral, y al que se atienen las partes en este caso, es diverso a otros -civil, tributario, o de familia, por ejemplo-, por la especial materia que se lleva a estrados, pero aquello no permite afirmar la absoluta autonomía del proceso laboral como rama. Lógicamente, las normas sobre competencia absoluta, en relación a la materia, contenidas en el artículo 420 o 485, no permiten sostener el carácter autónomo de la labor realizada por el juez laboral. En todo caso, él siempre estará desarrollando sólo la función jurisdiccional del Estado, y aquello, ha de realizarlo siempre respetando las normas de un debido proceso garantista.

La función jurisdiccional del Estado no admite una distinción interna que permita desentrañar nuevos fundamentos de la misma, y de esta forma, hacer pensable varias ideas de proceso en paralelo. En la misma dirección, la teoría general unitaria descarta dicha posibilidad, ahora desde la teoría procesal.

El proceso se materializa en un procedimiento que se ha generado dependiendo de las necesidades y requerimientos de cada área sustantiva del Derecho. Sin embargo, aquello no implica en ningún caso que cada procedimiento pueda ubicarse conceptualmente por sobre las premisas que hacen posible la existencia lógica de un proceso. O sea, si bien pueden existir procedimientos

\footnotetext{
33 "Forman parte del Poder Judicial, como tribunales especiales [...] Los Juzgados del Trabajo [...]" Artículo 5 inciso $3^{\circ}$ del Código Orgánico de Tribunales.

34 "Los juzgados a que se refieren los artículos anteriores son tribunales especiales integrantes del Poder Judicial [...]” Artículo 417 Código del Trabajo
} 
determinados por las respectivas materias que se traten en los litigios -bien por razones de conocimiento o experticia de los jueces en determinadas materias sustantivas, o por simple economía procesal-, aquello no puede implicar en ningún caso contrariar la noción misma de proceso, que supone a dos partes iguales puestas en contradicción dialéctica frente a un tercero que actúa de manera imparcial.

La Constitución, a su vez, no realiza ninguna distinción que permita señalar que el juez del trabajo no se encuentra sujeto al principio de juridicidad, pues este vincula a "todo órgano" del Estado. De hecho, la propia ley a la que hicimos referencia anteriormente, al ubicar a los juzgados del trabajo en el Poder Judicial, no deja lugar a discusión alguna sobre su sujeción al principio de juridicidad. Podría discutirse en qué casos ejerce jurisdicción, si es posible que realice alguna función administrativa, o inclusive, si tienen facultades legislativas con alcance general, pero inclusive así, en todos estos casos la discusión siempre partiría condicionada por el principio de juridicidad a que se encuentra sujeto en tanto órgano del Estado.

El juez del trabajo ejerce la función jurisdiccional del Estado, principalmente, respecto de los conflictos suscitados en la relación laboral entre empleador y trabajador. Será el vínculo de subordinación y dependencia el que defina la relación laboral entre estos privados. Sin embargo, ese elemento constitutivo de la relación laboral no puede traducirse de manera simple y directa en una intervención del Estado a través del juez en el desarrollo del Proceso. El Estado puede intervenir en instancias ajenas al desarrollo del proceso mismo si quiere beneficiar a una de las partes del contrato de trabajo por su posición desmejorada, como podría ocurrir con la creación de una defensoría laboral altamente eficiente e idóneamente capacitada, por ejemplo, u otorgando posibilidades de asesoramiento gratuito y continuo a la parte empleada, pero en ningún caso puede traducir sus expectativas por lograr el bien común, o los intereses que comprende desde ese concepto, en un actuar tendencioso del juez. En el caso de que así lo hiciese, el Estado a través del juez laboral ya no estaría ejerciendo su función jurisdiccional, pues no habría proceso, por definición, aunque habría un mero procedimiento, altamente invasivo de las garantías procesales, como el derecho a defensa, por ejemplo.

El juez laboral, por lo tanto, actúa en representación del Estado en el ejercicio de la función jurisdiccional de éste, y su finalidad en ese sentido es fundamentalmente resolver los conflictos intersubjetivos entre determinados agentes a través de un proceso judicial, que como tal, debe ceñirse a los presupuestos esenciales de su consagración constitucional, y además, al contenido doctrinario que brinda el garantismo procesal.

El juez laboral, en tanto agente del Estado, se encuentra sujeto al principio de juridicidad, y en ese sentido a él también se le prohíbe categóricamente la auto atribución de potestades, o la intervención activa en los aspectos materiales del proceso pues, como agente que ejerce jurisdicción, debe resguardar su posición imparcial, que asegura que resolverá el conflicto a través de un proceso, y no mediante la imposición autoritaria de una opción personal, que en el ejercicio del poder, se convierte una actuación arbitraria del poder estatal.

El razonamiento lógico es el siguiente: hay que recordar que incluso el juez laboral ha sido investido regularmente por el Estado para la satisfacción y cumplimiento precisamente de una función estatal, cual es la jurisdiccional. Esa función la ha de cumplir a través del proceso como método idóneo de solución de conflictos. En dicha labor, en tanto órgano del Estado, se encuentra sujeto al principio de juridicidad, en todas las dimensiones que comprende su tarea, y este principio a su vez ordena guardar el respeto del debido proceso en el ejercicio de las potestades específicas que se le han conferido. Sólo luego de dilucidar cuál es el rol del juez en nuestro orden Constitucional e institucional, en tanto agente público encargado de la función jurisdiccional del 
Estado, cabe asignar y reconocer para algunos de quienes está encargada la misma función, un grado de especialidad por materia. En concreto, será el ámbito de competencia que se reconoce al magistrado lo que determinará las especiales materias que se asignen para su conocimiento. En el caso del juez laboral, es la propia ley la que encarga un conocimiento especial definido por la materia, pero señalando expresamente que el juez de letras respectivo, y el juzgado, son parte del Poder Judicial. Además, sólo luego de aquello, la ley establece como forma de materialización de la función jurisdiccional que cumplirá - proceso-, una serie de reglas funcionales, reconocibles como procedimientos de carácter laboral; procedimiento de aplicación general, procedimiento de tutela, procedimiento monitorio, por ejemplo. Es ese el orden lógico que ha de seguir nuestro análisis, y que permite ubicar al juez concreto, y el ejercicio del poder que se le ha conferido, como una manifestación particular del poder del Estado.

En conclusión, todo lo señalado previamente sobre los Tribunales de Justicia, los jueces, y en general, sobre quiénes ejercen la función jurisdiccional del Estado materializada en el proceso, es plenamente aplicable al caso concreto del juez laboral, que queda sujeto ineludiblemente, y de manera positiva, al principio de juridicidad.

\section{EL PRINCIPIO DE LA BUENA FE PROCESAL COMO FUENTE DE POTESTADES ATÍPICAS EN EL PROCESO LABORAL}

\subsection{EL PRINCIPIO DE BUENA FE PROCESAL}

\subsubsection{Su consagración normativa}

En nuestro Código del Trabajo el principio de buena fe procesal encuentra su consagración expresa en los artículos 425 y 430. En efecto, el artículo 425 del Código del Trabajo señala: "Los procedimientos del Trabajo serán orales, públicos y concentrados. Primarán en ellos los principios de inmediación, impulso procesal de oficio, celeridad, buena fe, bilateralidad de la audiencia y gratuidad".

Dicho precepto viene a consagrar a la buena fe procesal como principio informante de todo procedimiento laboral, y como tal, en un primer acercamiento, pareciera que no es directamente aplicable y sancionable por parte del juez, por no tratarse de algún supuesto normativo típico conectado a una premisa inferior exigible a las partes o terceros, sino que más bien representa una inclusión de carácter amplio, que mira más al espíritu del juez en su tarea hermenéutica que a una fuente de deberes para los intervinientes en el proceso laboral.

Por otra parte, el artículo 430 inciso primero del Código del Trabajo establece que: "Los actos procesales deberán ejecutarse de buena fe, facultándose al tribunal para adoptar las medidas necesarias para impedir el fraude, la colusión, el abuso de derecho y las actuaciones dilatorias".

\subsubsection{La buena fe procesal: un concepto jurídico indeterminado}

Nuestro legislador no ha definido expresamente qué debemos comprender por buena fe procesal, sino que se limita a utilizar el concepto en los textos normativos previamente citados. Al no contar con una definición legislativa del concepto de buena fe procesal, debemos recurrir necesariamente a la doctrina a fin de esclarecer teóricamente cuál es su contenido y alcance. Aquí 
nos encontramos con la primera advertencia evidente: nos avocamos al estudio de un concepto jurídico indeterminado.

Desde que la discusión teórica sobre el concepto en cuestión ha sido puesta sobre la palestra, diversos autores han definido, cada uno a su manera, el contenido del concepto en cuestión. Así por ejemplo, Joan Picó i Junoy ${ }^{35}$, Juan Montero Aroca, Pablo Cifuentes ${ }^{36}$, Claudio Palavecino ${ }^{37}$, entre otros, han entregado cada uno, un concepto más o menos abierto sobre lo que sería el principio de buena fe procesal. Sin embargo, más allá de los elementos que permiten diferenciar cada una de sus conceptualizaciones, en todos estos casos se comparte la idea fundamental de que mediante la inclusión de la buena fe procesal se busca "dotar al procedimiento laboral de un influjo moralizante" 38 .

Es innegable el altísimo grado de incerteza jurídica que acarrea la consagración de éste concepto jurídico indeterminado en la legislación laboral nacional. Larroucau, en una visión tal vez un tanto pesimista de la situación afirma que:

"[T]ratándose de un concepto que es reflejo de una valoración social en constante cambio y, en consecuencia poseedora de una naturaleza constantemente dinámica, será imposible fijar su contenido con la debida precisión y permanencia a través de reglas genéricas que permitan establecer un estándar claro acerca de lo que en cada caso será buena o mala fe[...] De acuerdo con lo anterior y aun con el peligro de agravar la situación expuesta sólo nos quedará confiar en lo que resuelva cada juez, en cada caso concreto que se le presente $[\ldots]]^{\prime 39}$.

Si bien para el estudio de la institución de la buena fe, a secas, se puede recurrir a avances doctrinarios alcanzados en Derecho Civil, lo que permite diferenciar, por ejemplo, entre buena fe objetiva y subjetiva, no existe ningún precepto vigente que desde la propia definición legal permita inclinarse por alguna concepción concreta, o a lo menos, acercarse de manera razonable a alguna definición coherente con el debido proceso. Se puede afirmar que aparece palpable la intención moralizante del legislador, pero aquello no reduce en lo más mínimo su extrema vaguedad.

La fórmula utilizada por el legislador al consagrar el principio en cuestión, dificulta considerablemente el ejercicio hermenéutico que pudiese permitir la delimitación y alcance del precepto en análisis. Los conceptos e instituciones que acompañan a la buena fe procesal en el texto normativo del artículo 430 del Código del Trabajo, terminan por confundir aún más al operador jurídico, antes que colaborar con el elemento lógico de interpretación. El fraude, la colusión y el abuso de derecho, cada uno por sí sólo, representa para su óptima interpretación un alto nivel de

\footnotetext{
35 " $[\mathrm{L}] \mathrm{a}$ buena fe procesal puede definirse como aquella conducta exigible a toda persona, en el marco de un proceso, por ser socialmente admitida como correcta" Picó I Junoy, Joan. "El principio de la buena fe procesal" [en línea] Disponible en: <http:// www.justiciayderecho.org/revista 4/articulos/EL\%20PRINCIPIO\%20DE\%20LA\%20BUENA\%20FE\%20PROCESAL\%20 Joan\%20Pico\%20i\%20Junoi.pdf> [consultado 10 de marzo de 2014] p. 19.

36 Cifuentes, Pablo. "El deber de buena fe en los procedimientos laborales: noción, manifestación y problemática”, en: Revista chilena de derecho del trabajo y de la seguridad social, Vol.1 no2, Santiago, Chile, 2011, pp.91-108.

37 " $[\mathrm{u}] \mathrm{n}$ principio conforme al cual las partes tendrían un deber de probidad, lealtad, colaboración con la justicia y veracidad de los actos procesales". Palavecino Cáceres, Claudio. "El retorno del inquisidor. Las potestades judiciales en materia probatoria en el procedimiento laboral chileno”, en: Revista Latinoamericana de Derecho Social, n 13, julio-diciembre, México, 2011, pp.119-120.

38 Cifuentes, Pablo, op. cit. (n. 36), p. 91.

39 Larroucau García, María Matilde. "La buena fe procesal y el deber de colaboración de las partes en los procedimientos laborales", en: Revista chilena de derecho del trabajo y de la seguridad social, Vol. 1, n 1, Santiago, Chile, 2010, p. 70.
} 
complejidad doctrinaria. No sólo eso, sino que la doctrina ha podido diferenciar conceptualmente entre sí cada una de estas instituciones; y también cada una de ellas del principio de buena fe procesal. Misma tarea se ha llevado a cabo con algunos otros conceptos que darían lugar a confusión, como la teoría de los actos propios, por ejemplo ${ }^{40}$.

\subsubsection{El principio de buena fe procesal contra la juridicidad y el debido proceso}

Todo el estudio que pueda realizarse sobre el principio de buena fe procesal en el Proceso laboral, desde el principio de juridicidad, incluso antes del análisis de las potestad es conferidas al juez para el desarrollo de su función jurisdiccional, viene condicionado desde su fundamento por el criterio de supremacía Constitucional. En virtud de ésta, y por un criterio interpretativo compartido que ubica a la Constitución en la cima de la pirámide normativa, es necesario recordar previamente, que el principio de juridicidad, y el respeto al debido proceso, se encuentran ambos consagrados en la Constitución, mientras que el principio de buena fe procesal se encuentra regulado simplemente a nivel legal, en nuestro Código del Trabajo. Debido a esto, cualquiera se pretenda que sea el alcance del principio de buena fe procesal en el proceso laboral, dicha interpretación debe siempre y necesariamente respetar lo prescrito por la Constitución, y esto significa considerar primordialmente, entre otras garantías, el principio de juridicidad y el debido proceso.

Para adentrarnos al análisis del principio de buena fe procesal, desde el principio de juridicidad, es esencial observar la fórmula que utiliza el legislador en este caso para atribuir potestades al juez, supuestamente, con fines moralizantes. En ese sentido, ahora en su faz potestativa, debemos destacar, tal como señalamos previamente, que estamos en presencia de un concepto jurídico indeterminado, cuya laxitud se ve incrementada por su inclusión como "principio" en el proceso laboral.

Otorgar potestades a algún agente público mediante la utilización de conceptos jurídicos indeterminados, y en este caso especial, al juez, termina por atentar directamente contra la certeza jurídica, que es presupuesto del ejercicio de la libertad individual, y además, desde un punto de vista netamente procesal, vulnera groseramente el debido proceso, que según señala la propia Constitución, debe ser legalmente tramitado. En otras palabras, abre un amplio espacio para el camuflaje retórico de la arbitrariedad judicial, y con ello, para la actuación material activa del poder del Estado-Juez.

El eje polémico en los textos normativos que hemos citado previamente, y en los cuales se consagra el principio de buena fe procesal, consiste, en primer lugar, en la ya señalada indeterminación del concepto de buena fe procesal a nivel doctrinario y legal, lo que se traduce en el caso de nuestra legislación, en el establecimiento de una potestad abierta, indeterminada, o en otras palabras, no reglada. No es claro para nadie cuál es el contenido preciso de dicha acepción, y al revisar su consagración legal se vuelve aún más confusa su comprensión. Para determinar el supuesto de aplicación de la norma, necesariamente debemos comprender de manera clara cuál es la conducta que ha de activar una eventual sanción o actuación del juez, esto es, en general, en qué caso alguna actuación procesal no ha sido ejecutada de buena fe. En el artículo 430 del Código del Trabajo, la hipótesis de aplicación es ampliamente indeterminada e internamente variada -fraude, colusión, abuso de derecho y actuaciones dilatorias-, lo que permite deducir que el hecho jurídico que activa la potestad judicial -el por qué, como elemento de la potestad, según Soto Kloss- en este caso concreto, la supuesta actuación procesal que resulte contraria a la buena fe procesal, no

\footnotetext{
40 Montero Aroca, Juan. "Sobre el mito autoritario de la "buena fe procesal", en: Montero Aroca, Juan (Coord.). Proceso civil e ideología. Un prefacio, una sentencia, dos cartas y quince ensayos. Valencia, España: Tirant lo Blanch, 2006, pp. 340 y ss.
} 
se encuentra determinada en absoluto. En razón de lo expuesto, se deduce lógicamente que quién se encargará entonces de otorgarle un contenido cualquiera al principio de buena fe procesal será siempre el juez de la causa, quién interpretará el texto normativo, luego de seleccionar bajo su propio criterio los hechos concretos que considere relevantes, y de esta forma se convertirá él mismo en legislador del caso concreto, al crear en dicho análisis, la norma jurídica aplicable. Con esto, deja a las partes en total incertidumbre sobre los casos en los que se cumple efectivamente la hipótesis de aplicación de la norma, no pudiendo éstas prever en todo caso cuáles serían las actuaciones que les es legítimo realizar en el proceso, y arriesgándose así a caer en infracciones imprevisibles que pudiesen terminar por afectar sus intereses defendidos en juicio.

Pero no solo aquel elemento de la potestad se encuentra ampliamente indeterminado -el por qué-, sino que además no se tipifica la consecuencia, o premisa inferior del silogismo jurídico que configuraría la sanción de la norma. Desde el punto de vista de la atribución potestativa, dicha ausencia afectaría el elemento que define "qué" realizar en virtud de la potestad. En este punto entramos en otra esfera de amplia ambigüedad. El artículo 430 del Código del Trabajo, al utilizar la expresión "medidas necesarias", está abriendo la posibilidad de crear sanciones atípicas e innominadas por parte del juez, para los casos en que éste estime que se ha cumplido el presupuesto de actuación de la norma, o sea, la infracción al principio de buena fe procesal -también indeterminado-.

A diferencia del elemento potestativo que analizamos en un primer momento, coincidente con la hipótesis de aplicación de la norma -la indeterminación del principio de buena fe procesal-, en donde la utilización del concepto jurídico indeterminado abría espacio a la arbitrariedad del juez para decidir en qué casos se activará u operará la norma, en este segundo momento el legislador ha pretendido dejar directamente la creación completa de la premisa inferior de la norma jurídica a ser aplicada en manos del juez; deja en su completo poder la creación originaria de la sanción. Aquí ni siquiera nos encontramos ante un caso de atribución discrecional de la potestad, pues tal como definimos previamente, en tal caso el legislador habría determinado medios igualmente aptos, válidos y legítimos para la actuación del agente estatal, entre los cuales podría elegir con una libertad relativa. Sin embargo, en el precepto, la expresión "medidas necesarias" deja completamente abierto el abanico de vías alternativas que acabará por crear y aplicar el juez, para subsanar la infracción al principio de buena fe procesal. El legislador no se encargó de tipificar vías legítimas de actuación, otorgándole al juez la facultad de seleccionar una entre varías posibilidades igualmente válidas; por el contrario, deja abierto "el qué" de la potestad atribuida, al imaginario del juzgador.

La configuración potestativa en cuestión, tal como se desprende de lo descrito, no aprueba un examen de juridicidad en este ángulo de acercamiento pues en nuestro sistema jurídico no tiene cabida la atribución de potestades abiertas a ningún órgano del Estado, y en el caso descrito, la atribución atentaría contra el criterio de vinculación positiva y el principio de legalidad, contenido en el de juridicidad, que cubren al Estado por completo, en sus más diversas funciones.

Por la misma razón antes descrita, se descarta de entrada la posibilidad de que en virtud de la buena fe procesal existiesen potestades implícitas reconocidas al juzgador. En primer lugar, porque dicha teoría no tiene cabida en nuestro ordenamiento jurídico, y las discusiones sobre el tema se dan en un contexto completamente diferente al nuestro. Pero luego, además, porque en virtud del criterio de vinculación positiva, a través del cual leemos el principio de juridicidad, es imposible concebir que algún órgano del Estado se auto atribuya alguna potestad cualquiera; siempre requerirá habilitación legal previa y expresa para poder actuar válidamente, y el juez no es excepción a esta regla. Él podrá actuar válidamente sólo en los espacios en que la ley le ha orde- 
nado, y de la forma en que esta misma prescriba. Es necesario recordar una vez más que respect@ del Estado no rige el principio de la libertad, que sí rige a los particulares.

Empoderar al juez de la manera descrita atenta, por otro lado, contra el debido proceso, en tanto altera la posición de tercero imparcial que debe tener el juez en juicio. El juez, al brindarle contenido, tanto al principio de buena fe procesal, como a las medidas necesarias que decretará para evitar el fraude, la colusión, el abuso de derecho y las actuaciones dilatorias, genera una norma ad hoc desde las particularidades que él mismo encuentre en el caso. No es baladí analizar de qué lado pondrá el supuesto deber incumplido -y menos, qué deber-, puesto que dicha decisión, aunque no venga inducida previamente por la interferencia o intervención directa de alguna de las partes, denota una preferencia subjetiva por parte del juzgador hacia una de las dos posiciones antagónicas. Así, por ejemplo, si en virtud de la buena fe procesal solicita la presentación de pruebas que no ha presentado voluntariamente alguna de las partes, lo que está buscando el juez es simplemente confirmar su convencimiento personal inicial. Permite que el juez, de manera ilegítima, se vuelva un juez activista, e incluso, arbitrario. Afectará así, no sólo la necesaria imparcialidad del juzgador, sino inclusive el principio de igualdad de las partes en juicio.

Los preceptos en cuestión, de ser aplicados ampliamente, además vulneran la garantía de defensa procesal, al dejar abierta la posibilidad de creación de norma procesal ad hoc al juez, dejan a ambas partes sumidas por igual a la incerteza e imprevisibilidad casuística, que afecta directamente sus posibilidades de defensa en juicio, afectando además de esa manera, la regla del contradictorio.

Agréguese a todo lo previamente señalado, la incompatibilidad entre la función jurisdiccional y la función nomogenética, específicamente en el área procesal, que trataremos posteriormente a propósito del artículo 432 del Código del Trabajo, pues pareciese que en el fondo la determinación del concepto de buena fe procesal y la creación concreta de "medidas necesarias" por parte del juez, representan dos supuestos a los que el juez pudiese acogerse a fin de crear norma jurídica vinculante, sólo al caso concreto.

El principio de buena fe procesal, tal como ha sido fijado en el texto de la ley laboral, vulnera el principio de juridicidad en dos momentos. Primero, en la utilización de un concepto jurídico indeterminado en la descripción de la conducta que fundamenta la actuación del órgano; y segundo, en la determinación de las sanciones que acarreará la verificación de la conducta descrita indeterminadamente. Luego, el juez, simultáneamente y por añadidura, vulnera las garantías procesales consagradas constitucionalmente, y el principio de juridicidad, que las contiene.

\subsubsection{Alcances del principio de buena fe procesal conforme al principio de juridicidad}

Obviando la discusión sobre la procedencia de la acción de nulidad de derecho público en las resoluciones judiciales, creemos que una salida plausible a los eventuales casos vulneratorios del principio de juridicidad parte por la instrucción al juzgador de interpretar de manera restrictiva la ley procesal, evitando caer en arbitrariedades con ocasión de fundamentar una potestad jurisdiccional cualquiera en algún concepto jurídico indeterminado, como en nuestro caso es la buena fe procesal. En ese sentido, es preferible que el juzgador se atenga a aplicar la ley en los casos tipificados que sancionan de una u otra manera el respeto de la buena fe procesal.

Como manifestaciones legislativas del principio de buena fe procesal encontramos las siguientes: 
- Art. $453 \mathrm{n}^{\circ} 1$ inciso $7^{\circ}$-“Cuando el demandado no contestare la demanda, el juez, en la sentencia definitiva, podrá estimarlos como tácitamente admitidos”-[deber de completitud y colaboración].

-Art. $453 \mathrm{n}^{\circ} 5$-“[...] Cuando, sin causa justificada se omita la presentación de aquellos [instrumentos] que legalmente deban obrar en poder de una de las partes podrán estimarse probadas las alegaciones hechas por la parte contraria en relación con la prueba decretada”- [deber de cooperación].

- Art 454 n³ - "Si el llamado a confesar no compareciese a la audiencia sin causa justificada, o compareciendo se negase a declarar o diese respuestas evasivas, podrán presumirse efectivas, en relación con los hechos objeto de prueba, las alegaciones de la parte contraria en la demanda o contestación, según corresponda"- [deber de completitud y colaboración].

- Art. 429 CT -"No podrá solicitar la declaración de nulidad la parte que ha originado el vicio o concurrido a su materialización"- [deber de buena fe procesal en sentido estricto].

- Art. 454 n5 CT - “Los testigos declararán bajo juramento, o promesa, de decir la verdad en juicio"- [deber de veracidad con alcance a terceros].

- Art. 444. En este punto cabe preguntarse: ¿La función cautelar del juez es manifestación del principio de buena fe procesal? [Las medidas que estime necesarias para: asegurar el resultado de la acción, protección de un derecho o identificación de los obligados y la singularización de su patrimonio en términos suficientes para garantizar el monto de lo demandado] Esto pudiese comprenderse en este sentido si se entiende que cumple con una especie de deber de probidad y compromiso con la verdad al decretar las medidas que estime convenientes -en realidad, lo que no es sino lo mismo, las necesarias-.

Las normas enunciadas también deben ser aplicadas restrictivamente, intentando en todo caso no crear deberes que las partes pudiesen desconocer al enfrentarse en juicio, para de esa manera no afectar su derecho a defensa, y el debido proceso.

\section{CONCLUSIONES}

El principio de juridicidad tiene plena vigencia en nuestro ordenamiento jurídico, y encuentra su consagración vinculante en la norma suprema. Cubre por completo las actuaciones de absolutamente todos los órganos del Estado, sin excepción alguna. Por ello nos permitimos concluir que también los tribunales de justicia se encuentran sujetos al contenido de dicho principio regulador de la actividad estatal, y en especial los Tribunales del Trabajo.

La noción sobre los fines del proceso que aparece más coherente con nuestra Carta Fundamental de espíritu eminentemente libertario es la doctrina del garantismo procesal, y por lo mismo, debemos abordar la institución del proceso de manera simultánea desde dicha doctrina y el principio de juridicidad.

De la conjunción anterior se deduce, entre otras consecuencias, la imposibilidad de atribuir potestades innominadas o atípicas al juez laboral, pues él, en tanto órgano del Estado que ejerce la función jurisdiccional, también se encuentra sujeto al principio de juridicidad, y en especial al criterio de vinculación positiva.

El Código del Trabajo regula el proceso inspirado en un espíritu eminentemente activista e inquisitivo, contrariando en muchos casos lo contenido en disposiciones constitucionales de rango superior. En particular hemos descubierto una serie de atribuciones potestativas que pueden parecer otorgar un poder amplio al juez, en favor de una comprensión oficiosa del proceso. 
Así, por ejemplo, la norma relativa al principio de la buena fe procesal que tratamos en nuestra investigación.

El juez, con la finalidad de no vulnerar las garantías procesales fundamentales, debe procurar interpretar de manera restrictiva las disposiciones que permiten discutir la posibilidad de auto atribuciones potestativas, puesto que en caso contrario vulneraría el principio dispositivo, y el supremo principio de juridicidad de las actuaciones de los órganos del Estado. En caso contrario, su actuar sería ilegítimo, y la noción de proceso sería de tal forma desvirtuada que aparecería desnaturalizada por completo, a lo sumo transformándose en un mero procedimiento unilateral de carácter oficioso, en que las partes más que sujetos de derecho cuyos intereses merecen protección, pasan a ser instrumentalizados en favor del desarrollo mismo de la actividad pública, transformándose de esa forma el juez en el actor central del litigio, desplazando a los particulares y el desarrollo dialéctico contradictorio a un papel secundario; en el fondo, vulnera el principio de primacía de la persona humana consagrado en nuestra Constitución, y con ello, desarmoniza por completo la comprensión de nuestro ordenamiento jurídico.

\section{BIBLIOGRAFÍA}

Academia Judicial. Manual de juicio del trabajo. Santiago, Chile: Academia Judicial, Santiago, Chile, 2008.

Alarcón Jaña, Pablo Andrés. Discrecionalidad administrativa. Un estudio de la jurisprudencia chilena. Santiago, Chile: Editorial Jurídica ConoSur Ltda., 2000.

Aldunate Lizana, Eduardo. "La independencia judicial: aproximación teórica, consagración constitucional, y crítica", en: Revista de Derecho de la Universidad Católica de Valparaíso, nº XVI, Valparaíso, Chile, 1995.

Aldunate Lizana, Eduardo. "La constitución monárquica del Poder Judicial", en: XXXII Jornadas de Derecho Público, Revista de Derecho de la Universidad Católica de Valparaíso, no XXII, Vol. I, 2001.

Alvarado Velloso, Adolfo. Cautela Procesal (critica a las medidas precautorias). Rosario, Argentina: Editorial Iuris, 2008.

Alvarado Velloso, Adolfo. Lecciones de derecho procesal civil. Botтo OAKLey, Hugo (Adaptador). Santiago, Chile: Punto Lex, Thomson Reuters, 2011.

Appes, Jorge. Principio de congruencia, en: Águila Grados, Guido; Calderón Sumarriva, Ana. La fe del hombre en sí mismo o la lucha por la libertad a través del proceso. El mundo procesal rinde homenaje al Maestro Adolfo Alvarado Velloso, EGACAL, 2008, p. 236 [en línea] Disponible en: < http://egacal.e-ducativa.com/upload/ AAV_JorgeAppes.pdf> [Consultado el 05 de Agosto de 2014]

Atria Lemaitre, Fernando. "Jurisdicción e Independencia Judicial: el poder judicial como poder nulo", en: Revista de Estudios de la Justicia, ${ }^{\circ}{ }^{\circ}$, Santiago, Chile, 2004.

Bermúdez Soto, Jorge. "El principio de legalidad y la nulidad de Derecho Público en la Constitución Política. Fundamentos para la aplicación de una solución de Derecho Común”, en: Revista de Derecho Público, Vol. 70, Santiago, Chile, 2008.

Bordalí Salamanca, Andrés. "La doctrina de la separación de poderes y el poder judicial chileno", en: Revista de Derecho de la Pontificia Universidad Católica de Valparaíso, n 30, Valparaíso, Chile, 2008, [En línea]. [Consultado 20 de Marzo de 2012] < http://www.scielo.cl/pdf/rdpucv/n30/art04.pdf>

Bordalí Salamanca, Andrés. "Diversos significados de la tutela cautelar en el proceso civil”, en: Revista de derecho, Vol. 12, n², Valdivia, Chile, 2001.

Bordenave, Leonardo. "La regla de congruencia y su flexibilización”, en: Águila Grados, Guido; Calderón Sumarriva, Ana. La fe del hombre en si mismo o la lucha por la libertad a través del proceso. El mundo procesal rinde homenaje al Maestro Adolfo Alvarado Velloso, EGACAL, 2008, p. 306 [en línea] Disponible en: < http://egacal.educativa.com/upload/AAV_LeonardoBordenave.pdf> [Consultado el 05 de Agosto de 2014] 
Botto Oakley, Hugo. "Límites o alcances del debido proceso conforme a la constitución, desde la óptica de la iniciativa probatoria", en: Fuente Paredes, Paulo de la (Coord.). Estudios de derecho procesal civil: bases para un nuevo código procesal civil. Santiago, Chile: Librotecnia, 2010.

Calamandrei, Piero. Introducción al estudio sistemático de las providencias cautelares. Traducción de Sentis Melendo. Buenos Aires, Argentina, 1945.

Caldera Delgado, Hugo. Sistema de la responsabilidad extracontractual del estado en la constitución política de 1980. Santiago, Chile: Editorial Jurídica de Chile, 1982.

Caldera Delgado, Hugo. Tratado de Derecho Administrativo. Tomo I. Santiago, Chile: Ediciones Parlamento, 2001.

Carmona Santander, Carlos. "La Responsabilidad del Estado-Juez. Revisión y Proyecciones", en: Revista de Derecho Público, n 66, Santiago, Chile, 2004.

Carocca PÉREZ, Alex. Garantía constitucional de la defensa procesal. Santiago, Chile: Ediciones jurídicas Olejnik y J.M.Bosch editor, 1998.

Cea Egaña, José Luis. Derecho Constitucional Chileno. -2º edición-. Santiago, Chile: Ediciones Universidad Católica de Chile, Santiago, 2008.

Cifuentes, Pablo. "El deber de buena fe en los procedimientos laborales: noción, manifestación y problemática", en: Revista chilena de derecho del trabajo y de la seguridad social, Vol.1 n²2, Santiago, Chile, 2011.

Devillaine, Franco; Palavecino Cáceres, Claudio. "Sobre la naturaleza del procedimiento de tutela laboral”, en: $L a$ Semana Jurídica, n 382, noviembre, Santiago, Chile, 2008.

Fiamma Olivares, Gustavo. "Acción constitucional de nulidad y legitimación activa objetiva", en: Revista de Derecho Público, n 49, Santiago, Chile, 1991.

Gamonal Contreras, Sergio. El procedimiento de tutela de derechos laborales. -2a edición-. Santiago, Chile: LegalPublishing, , 2008.

García Malgarejo, Flavia. "Idea de Verdad y regla de la congruencia”, en: en: Águila Grados, Guido; Calderón Sumarriva, Ana. La fe del hombre en sí mismo o la lucha por la libertad a través del proceso. El mundo procesal rinde homenaje al Maestro Adolfo Alvarado Velloso, EGACAL, 2008, p. 199 [en línea] Disponible en: < http:// egacal.e-ducativa.com/upload/AAV_FlaviaGarcia.pdf> [Consultado el 05 de Agosto de 2014]

Lanata Fuenzalida, Gabriela. Manual de proceso laboral. Santiago, Chile: Editorial AbeledoPerrot, 2010.

Larroucau García, María Matilde. "La buena fe procesal y el deber de colaboración de las partes en los procedimientos laborales", en: Revista chilena de derecho del trabajo y de la seguridad social, Vol. 1, nº 1, Santiago, Chile, 2010.

Marín, Juan Carlos. "Las medidas cautelares en el ordenamiento jurídico chileno: su tratamiento en algunas leyes especiales", en: Revista de Estudios de la Justicia, no 8, Santiago, Chile, 2006.

Marzi, Daniela. "¿Quién le teme a los derechos fundamentales? Sobre el procedimiento de tutela de la reforma laboral”, en: Anuario de Derechos Humanos, n 6, Santiago, Chile, 2010.

Martínez Estay, José Ignacio. "Algunas reflexiones sobre la nulidad de derecho público". [en línea] Documento de Trabajo $\mathrm{n}^{\circ}$ 56, Facultad de Derecho Universidad de los Andes, 2003. [En línea] Disponible en: <http:// biblioteca.uandes.cl/documentos/DesplegarTesis.asp?nombre=C:/www/biblioteca/documentos/JIMartinez. xml> [Consultado 03 de Julio de 2014]

Montero Aroca, Juan. "Sobre el mito autoritario de la "buena fe procesal", en: Montero Aroca, Juan (Coord.). Proceso civil e ideología. Un prefacio, una sentencia, dos cartas y quince ensayos. Valencia, España: Tirant lo Blanch, 2006.

Palavecino Cáceres, Claudio. "El retorno del inquisidor. Las potestades judiciales en materia probatoria en el procedimiento laboral chileno", en: Revista Latinoamericana de Derecho Social, $\mathrm{n}^{\circ} 13$, julio-diciembre, México, 2011.

Palavecino Cáceres, Claudio. "Sistemas procesales e ideologías", en: Revista Derecho y Humanidades, $n^{\circ}$ 17, Santiago, Chile, 2012. 
Picó I Junoy, Joan. "El principio de la buena fe procesal" [en línea] Disponible en: <http://www.justiciayderecho.org/ revista4/articulos/EL\%20PRINCIPIO\%20DE\%20LA\%20BUENA\%20FE\%20PROCESAL\%20Joan\%20 Pico\%20i\%20Junoi.pdf> [consultado 10 de marzo de 2014].

Reyes Riveros, Jorge. "El principio de juridicidad y la modernidad", en: Revista chilena de derecho, Vol. 25, no 1, Santiago, Chile, 1998.

Reyes Riveros, Jorge. "Los principios aplicables respecto del papel instrumental del Estado frente a los derechos y deberes de las personas", en: Revista de Derecho Público, Vol. 62, Santiago, Chile, 2000.

Soto Kloss, Eduardo. "Responsabilidad del Estado por la actividad jurisdiccional (notas para un enfoque unitario de la responsabilidad extracontractual del Estado)", en: Revista chilena de derecho, Vol. 10, no 1, Santiago, Chile, 1983.

Soto Kloss, Eduardo. Derecho Administrativo: Bases fundamentales. Tomo II. Santiago, Chile: Editorial Jurídica de Chile, 1996.

Soto Kloss, Eduardo. "La nulidad de derecho público: su actualidad", en: Revista de Derecho de la Pontificia Universidad Católica de Valparaíso, n 18, Valparaíso, Chile, 1997.

Soto Kloss, Eduardo. Prólogo, en: Alarcón Jaña, Pablo Andrés. Discrecionalidad administrativa. Un estudio de la jurisprudencia chilena. Santiago, Chile: Editorial Jurídica ConoSur Ltda., 2000.

Ugarte Cataldo, José Luis. Tutela de derechos fundamentales del trabajador. Santiago, Chile: LegalPublishing, 2009. 